\title{
原著論文
}

\section{局所麻酔薬バイアルおよび輸液ボトルの ゴム栓の無菌性}

奥田みのり* 一戸達也 ${ }^{*}$ 金子 譲*

[要旨］市販の未開封局所麻酔薬バイアル，全身麻酔薬バイアルおよび輸液ボトルの ゴム栓の無菌性と, 消毒用アルコール綿によるゴム栓清拭の意義について検討した． また，これらの薬剤が菌によって污染された場合にどのような発育を示すのかについ ても観察した. バイアルのカバーを取り除いた直後のゴム栓には，細菌および真菌が 検出されなかった．しかし，アルコ一ル綿で清拭した後では，20\%に真菌の集落が 検出された. リドカインバイアルに Staphylococcus aureus ならびに Candida albicansを播種したところ，生菌数は経時的に減少した。しかし，プロポフォール バイアルや輸液ボトルに播種された菌は 24 時間以降有意に増加した.

キーワード : ゴム栓，輸液製剤，細菌・真菌

（日臨麻会誌 Vol.21 No.3, 156～159, 2001）

\section{はじめに}

開封前の局所麻酔薬のバイアルや輸液製剂のゴム 栓は微生物による污染が考えられるので，使用前に 消毒用アルコール綿で清拭するべきであるといわ扎 ており，一部の添付されている薬品説明書 $(0.5 \%$ 力 ルボカイン注，アストラゼネカ株式会社の添付文書 中の取り扱い上の注意の項目)にもその処置が記載 されている，しかし，市販されている局所麻酔薬の バイアルのゴム栓の無菌性を調べた報告はなく，ア ルコール綿清拭の有効性も不明である.

そこでわれわれは，未開封のバイアルおよび輸液 ボトルのゴム栓の無菌性およびアルコール清拭の効 果について検討した。また実際に微生物がバイアル や輸液ボトルに侵入した場合に，溶液中で微生物が 発育をするのか否かについて調べた結果を報告する。

\section{I 対象と方法}

実験 1 として，局所麻酔薬リドカイン $20 \mathrm{~m} l$ バイア ル(キシロカイン注射液 $1 \%$ ，アストラゼネカ株式会 社) 10 バイアル，全身麻酔薬プロポフォール $50 \mathrm{ml}$ バ イアル(1％ディプリバン注，アストラゼネカ株式会 社) 10 バイアルおよび輸液 $250 \mathrm{ml}$ ボトル(生理食塩液, 光製薬株式会社製) 20 ボトル，いずれも未開封のも のを対象とした. 局所麻酔薬リドカインバイアルは, (1)キャップを外した直後のゴム栓を滅菌リン酸緩衝 生理的食塩液(PBS, pH 7.4)に浸した滅菌綿棒で拭 い,その同じゴム栓を(2)手指で軽く絞った $70 \%$ 消毒 用アルコール綿で清拭した後に滅菌綿棒で拭ったも の，それぞれを検体とした。この 2 種類の検体を Trypticase soy agar (BBL Microbiological Systems) にウマ脱線維血液 $10 \%$, hemin $5 \mu \mathrm{g} \cdot \mathrm{m} l^{-1}$ および 
表 1 局所麻酔薬, 全身麻酔薬および輸液ボトルゴム栓 からの細菌・真菌類の検出結果

\begin{tabular}{|c|c|c|c|}
\hline \multirow[b]{2}{*}{ 対 } & \multirow[b]{2}{*}{$\mathrm{n}$} & \multicolumn{2}{|c|}{ 菌が検出された培地数 } \\
\hline & & $\begin{array}{l}\text { 血液寒天 } \\
\text { 培地 }\end{array}$ & $\begin{array}{l}\text { カンジダ } \\
\text { GE 培地 }\end{array}$ \\
\hline \multicolumn{4}{|l|}{ リドカインバイアル } \\
\hline 開封直後 & 10 & 0 & 0 \\
\hline アルコール清拭後 & 10 & $2^{*}$ & 0 \\
\hline \multicolumn{4}{|c|}{ プロポフォールバイアル } \\
\hline 開封直後 & 10 & 0 & 0 \\
\hline \multicolumn{4}{|l|}{ 輸液ボトル } \\
\hline 開封直後 & 20 & 0 & 0 \\
\hline
\end{tabular}

menadione $0.5 \mu \mathrm{g} \cdot \mathrm{m} l^{-1}$ の割合で添加した血液寒天 培地およびカンジダ選択培地(カンジダ $\mathrm{GE}$ 培地, 日 水製薬株式会社）に塗布した。プロポフォールバイ アルと輸液ボトルは開封直後のゴム栓を滅菌綿棒で 拭い, ウマ血液寒天培地およびカンジダ GE培地に 塗布した。これらの操作はクリーンベンチ内で行っ た.クリーンベンチ内での落下細菌の污染のないこ とは, ウマ血液寒天培地を用いて確認した。培養を $37^{\circ} \mathrm{C}$ 好気条件下で 1 週間行った後に，コロニー数 (colony forming unit：CFU)の計測をした.

実験 2 として，未開封の輸液用生理食塩液 $500 \mathrm{~m} l$ ボトル $($ 生理食塩液, 光製薬株式会社製 $)$, 糖を含む 輸液用電解質液 $500 \mathrm{~m} l$ ボトル(ソリタ $\mathrm{T}-4$ 号, 武田 薬品工業株式会社), $1 \%$ リドカイン $20 \mathrm{ml}$ バイアル (キシロカイン注射液 $1 \%$, アストラゼネカ株式会社), プロポフォール $50 \mathrm{ml}$ バイアル $(1 \%$ \%ティプリバン注, アストラゼネカ株式会社) 各 4 ボトルおよび4バイア ルを対象とした。供試した細菌および真菌は Staphylococcus aureus (FDA209-P株), Candida albicans〔ヒトロ腔内から分離した MINO株で slide culture 法およびカンジダ迅速鑑別用培地クロモス ラントカンジダカラー(関東化学株式会社)にて確認 されたもの]を使用した。これらの株は，それぞれ の培地で 24 時間培養し, 滅菌PBSにて懸濁した。こ の懸濁液を約 $1 \times 10^{8} \mathrm{CFU} \cdot \mathrm{m} l^{-1}\left(\mathrm{OD}_{660}\right.$ で 0.2$)$ となる よう滅菌PBSにて希釈し, ウマ血液寒天培地上で計 測しやすい菌数に調整した. C. albicans はそのまま,

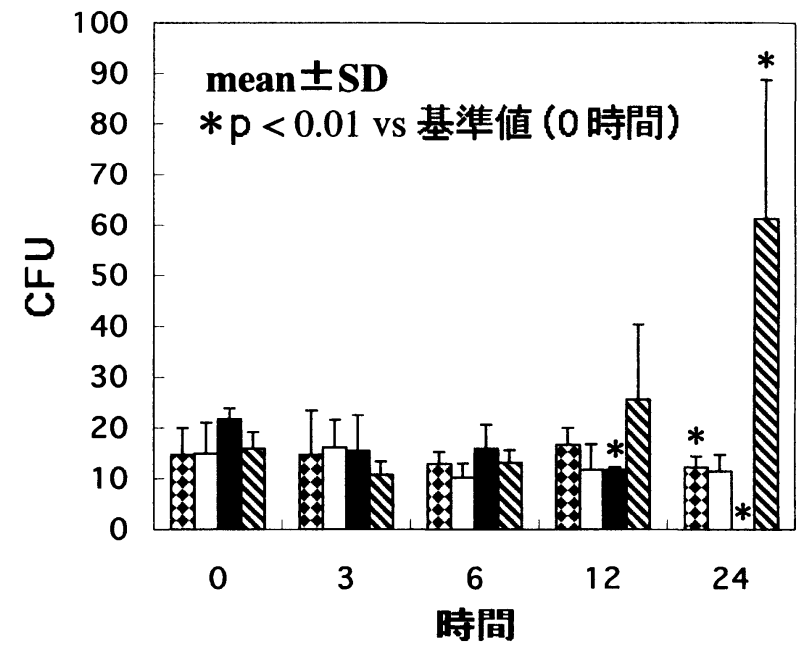

図1Staphylococcus aureus播種後のバイアルおよび 輸液ボトル中の菌数の経時的変移

因生理食塩液，口糖を含む輸液用電解質液， $1 \%$ リ ドカイン, $\mathbf{N フ ゚ ロ ホ ゚ フ ォ ー ル ~}$

S. aureus についてはさらに $1 / 50$ の濃度になるよう 希釈し，これを各輸液ボトルおよびバイアル中に $1 \%$ の溶液になるよう注入した。輸液ボトルおよび バイアルは約 $20^{\circ} \mathrm{C}$ 室温下におき，0，3，6，12, 24 時間後 (カンジダは 48 時間後まで)に $100 \mu l$ ずつ採 取し, ウマ血液寒天培地に塗布した。培養は $37^{\circ} \mathrm{C}$ 好 気条件下で 1 週間行い，コロニー数を計測した。

生菌数はコロニー数を平均土標準偏差で示した。 輸液ボトルおよびバイアル中の菌数の経時的変化に 対して Friedman 検定を行い，各時間における 4 群 間の比較はKruskal-Wallis 検定を行い, 多重比較で はStudent-Newman-Keuls 法を行った。

\section{II 結 果}

実験 1 において, 各バイアルおよび輸液ボトルの ゴム栓では, 開封直後の検体からは細菌および真菌 のコロニーは検出されなかった。しかし，アルコー ル綿で清拭した後，10バイアル中 2 バイアルから真 菌が検出された。培養された真菌は, slide culture 法による形態学的観察および生化学的性状検査から C. albicans 以外のカンジダと考えられた(表 1).

実験 2 において 24 時間後, リドカインバイアルに 


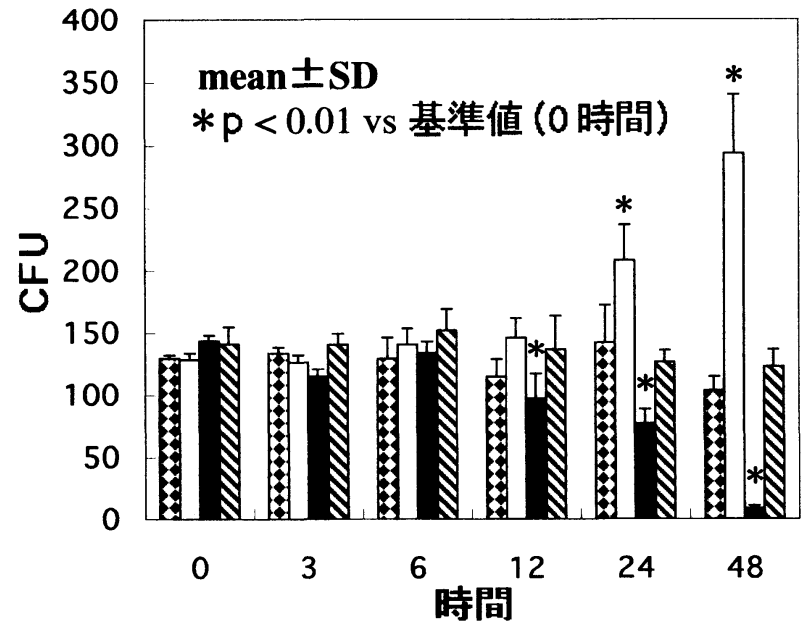

図2 Candida albicans播種後のバイアルおよび輸液ボ トル中の菌数の経時的変移

回生理食塩液, 口糖を含む輸夜用電解質液, $\mathbf{\square} 1 \%$ リ ドカイン, $\mathbb{N フ ゚ ロ ホ ゚ フ ォ ー ル ~}$

播種した S. aureusは有意に減少したが $(\mathrm{p}<0.01)$, プロポフォール中では有意に増加した $(\mathrm{p}<0.01)$ (図1). C. albicansの生菌数は 12 時間以降リドカイン中で有 意に減少し $(\mathrm{p}<0.01), 24$ 時間以降糖を含む輸液用 電解質液中では有意に増加した $(\mathrm{p}<0.01)$ 。C. albicansの播種菌株の増減は, プロポフォールについて はサンプリング期間中に有意差が認められなかった (図2).

\section{III 考察}

実験 1 において，開封直後の輸液ボトル，局所麻 酔薬バイアルおよび全身麻酔薬バイアルのいずれの ゴム栓からも, ウマ血液寒天培地ならびにカンジダ $\mathrm{GE}$ 培地で細菌・真菌のコロニーは検出されず無菌 的であるといえた。今回の研究結果は，多くの診療 現場で実施されている消毒用アルコール綿で清拭す る方法でバイアルのゴム栓が真菌類に污染される可 能性があることを示した。真菌の芽胞はアルコール では殺菌されないため、検出された真菌は手指から アルコール綿を介してゴム栓に付着した可能性も示 唆される。このため，手指に付着している微生物に 污染されないよう，1本 1 本のバイアルにゴム栓を
保護するキャップをつけることで，アルコール綿で 拭う操作をなくすべきであると思われる。

実験 2 において S. aureusは, 防腐剤や抗菌薬が含 まれていないプロポフォール中において室温下でも 有意な増加を示した。プロポフォールは開封直後に 使用しなければならないと添付されている薬品説明 書にも記載されているが，ICUにおける鎮静に使用 される場合には長時間室温下に同じバイアルやシリ ンジ内で使用される可能性もある。そのような場合 にはゴム栓穿刺時や，シリンジのセッティング時の 污染に注意しなくてはならない。 また，S. aureusは 糖を含む輸液用電解質液や生理食塩液中で発育促進 はみられなかったものの生菌数はほぼ維持されてお り，污染された場合の感染性リスクの高いことを示 唆している.

一方，S. aureus とは異なり，C. albicansは糖を含 む輸液用電解質液中において増加が認められた。こ れは真菌と細菌の栄養要求性の違いによるものと思 われた。

$1 \%$ 1\%吕インバイアル中では, 播種した細菌・ 真菌はともに減少した。これはリドカインのもつ抗

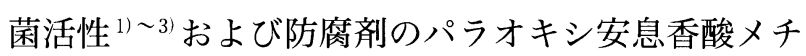
ルの効果によるものであると考えられた。

信頼のおける医療には医原性の感染事故があって はならない.マルチドーズバイアルの污染やプロポ フォールの污染による周術期感染が報告されてお り，しかも污染された麻酔薬と麻酔科医の手から検 出された菌株が同じだったという報告がある ${ }^{4)}$ 。つ まり麻酔薬および輸液製剤の污染は手術室での開封 操作や調剤時，および針の差し替え時の不適切な操 作で起こる可能性が高い. 麻酔薬および輸液製剤は 使用直前に開封し, 開封したらゴム栓には触れずに すぐに使用し，極力無菌操作を心がけることを基本 とするべきである。加えて手術室で働く医療スタッ フはよく手洗いをして常に手指を清潔に保ち，污染 の疑いのあるものはすぐに破棄することが肝要で ある。 
本稿の要旨は, 日本臨床麻酔学会第 19 回大会 (1999，東京)で発表した。

謝辞 本研究においてご協力いただいた東京歯科 大学微生物学教室 石原和幸講師はじめ教室の先生 方に感謝致します。

\section{参考文献}

1) Schmidt RM, Rozenkrantz HS : Antimicrobial activity of local anesthetics. J Infect Dis $121: 597 \sim 607,1979$

2) Fazly Bazaz BS, Salt WG : Local anesthetics as antimicrobial agents : structure-action considerations. Microbios $37: 45 \sim 64,1983$

3) Longfield R, Longfield J, Smith P, et al. : Multidose medication vial sterility : An in-use study and a review of the literature. Infect Control $5: 165 \sim 169$, 1984

4) Bennett SN, McNeil MM, Bland LA, et al. : Postoperative infections traced to contamination of an intravenous anesthetic, propofol. N Engl J Med 333 : 147 154, 1995

\title{
Sterility of Rubber Septum of Vial and Transfusion Bottle
}

\author{
Minori OKUDA, Tatsuya ICHINOHE, Yuzuru KANEKO \\ Department of Dental Anesthesiology, Tokyo Dental College
}

We studied the sterility of the rubber septums on anesthetic vials and a transfusion bottle and evaluated the disinfection with alcohol-soaked cotton. Neither bacterial nor fungal cells were detected on the rubber septum of the vials by the culture method, while fungal cells were detected in 2 out of 10 vials after swabbing with alcohol-soaked cotton. Staphylococcus aureus and Candida albicans cells were inoculated in anesthetic vials and a transfusion bottle, and their growth was observed. The viable numbers of both organisms was reduced in the lidocaine vial, although increasing numbers were observed in the propofol vial and the transfusion bottle.

Key Words : Rubber septum, Transfusion bottle, Microorganism

The Journal of Japan Society for Clinical Anesthesia Vol.21 No.3, 2001 